\title{
Mass variation in outcome to high production activity in Kamojang Geothermal Field, Indonesia: A reservoir monitoring with relative and absolute gravimetry
}

\author{
Yayan Sofyan ${ }^{1,2}$, Yustin Kamah $^{3}$, Jun Nishijima ${ }^{4}$, Yasuhiro Fujimitsu ${ }^{4}$, Sachio Ehara ${ }^{4}$, Yoichi Fukuda ${ }^{5}$, and Makoto Taniguchi ${ }^{6}$ \\ ${ }^{1}$ Aso Volcanological Laboratory, Graduate School of Science, Kyoto University, Minami Aso, Aso, Kumamoto 869-1404, Japan \\ ${ }^{2}$ Department of Physics, Faculty of Mathematics and Natural Sciences, University of Indonesia, Depok, Indonesia \\ ${ }^{3}$ PERTAMINA, Indonesia \\ ${ }^{4}$ Department of Earth Resources Engineering, Faculty of Engineering, Kyushu University, \\ 744 Motooka, Nishi-ku, Fukuoka 819-0395, Japan \\ ${ }^{5}$ Graduate School of Science, Kyoto University, Kitashirakawa, Oiwake-cho, Kyoto 606-8502, Japan \\ ${ }^{6}$ Research Institute for Humanity and Nature (RIHN)
}

(Received March 2, 2011; Revised June 27, 2011; Accepted July 8, 2011; Online published February 14, 2012)

\begin{abstract}
The Kamojang Geothermal Field (KGF) is a typical vapor dominated hydrothermal system in west Java, Indonesia. This geothermal eld is the oldest exploited geothermal eld in Indonesia. From 1983 to 2005, more than 160 million tons of steam has been exploited from the KGF and more than 30 million tons of condensed water and river water were injected to the reservoir system. Regarding to the electricity demand, installed capacity of KGF increased from 30 MWe to 140 MWe in 1987 and 200 MWe in 2007. Mass variation in the geothermal reservoir can be measured by using the map of the gravity changes. Gravity changes observed in the KGF between 1999 and 2005 at 51 benchmarks are interpreted in terms of a change of mass. Concerning to the production mass increase, gravity changes also observed between 1999 and 2008 at 30 benchmarks. The recent gravity measurement was conducted using absolute gravimeter in 2009 and 2010 at 12 gravity benchmarks. Mass variation in the reservoir was caused by production and injection activities. Mass variation in KGF from 1999 to 2005 is about -3.34 Mt/year while is about -3.78 Mt/year from 1999 to 2008. Another period between 2009 and 2010, mass variation decreased about $-8.24 \mathrm{Mt}$. According to the history of production and injection, natural recharge to the KGF's reservoir is estimated at about $2.77 \mathrm{Mt} /$ year from 1999 to 2005 and $2.75 \mathrm{Mt} / \mathrm{year}$ from 1999 to 2008. Between 2009 and 2010, KGF has a bigger mass de ciency rate throughout 200 MWe maintain production.
\end{abstract}

Key words: Mass variation, gravity changes, Kamojang Geothermal Field, Indonesia.

\section{Introduction}

Kamojang Geothermal Field in the Garut region of west Java, about $40 \mathrm{~km}$ from the city of Bandung, is a vapordominated system with a reservoir depth of about 600 to $2000 \mathrm{~m}$. The KGF is located on the geographical coordinate of $07^{\circ} 11^{\prime} 02^{\prime \prime}-07^{\circ} 06^{\prime} 08^{\prime \prime} \mathrm{S}$ and $107^{\circ} 44^{\prime} 36^{\prime \prime}-107^{\circ} 49^{\prime} 30^{\prime \prime} \mathrm{E}$. The Kamojang geothermal system resulted from the complex interaction between active volcanoes and tectonic processes and it is in uenced by two important faults named the Kendang fault and the Citepus fault (Sudarman et al., 1995; Kamah et al., 2005). The area of the KGF is about $21 \mathrm{~km}^{2}$ and it has altitude of about $1400-1800 \mathrm{~m}$ above sea level (Fig. 1). The Kamojang geothermal reservoir is covered by the cap rock that consists of prophylitic altered volcanic rock of which thickness is about 500-600 m but seems to be only 200-300 m thick toward to the northern and eastern parts. The productive geothermal reservoir, which has high porosity, high permeability, high temperature, and

Copyright (C) The Society of Geomagnetism and Earth, Planetary and Space Sciences (SGEPSS); The Seismological Society of Japan; The Volcanological Society of Japan; The Geodetic Society of Japan; The Japanese Society for Planetary Sciences; TERRAPUB.

doi:10.5047/eps.2011.07.005 lled with suf cient steam, is located between 600-2000 m in depth. Reservoir consists of the strongly altered andesitic rocks and some volcanic pyroclastics (Sumintadireja et al., 2000).

Geothermal exploration in the KGF has begun in the early 20th century by The Dutch. In the 1920, the shallow test wells at Kamojang were drilled successfully. The rst electrical power at Kamojang was generated in 1978 when a small (mono block $250 \mathrm{kWe}$ ), free exhaust-type turbine was installed and then the design of the rst large-scale geothermal power plant was completed in 1979 (Hochstein and Sudarman, 2008). In late 1982, production of $30 \mathrm{MWe}$ (Unit I) was started in KGF. Development drilling continued and two 55 MWe units (Units II and III) were added in 1987. In the end of 2007, a 60 MWe (unit IV) was added to complete a 200 MWe installed capacity in KGF (Sofyan et al., 2010). Pertamina has drilled wells with bottom holes temperatures ranging from 115 to $245^{\circ} \mathrm{C}$ (Moeljanto, 2004). The three to ve deep unproductive wells, situated in the center of the eld, have been used as injection wells. Concerning to the evaluation of the steam production in the $\mathrm{KGF}$, the decline of steam ow rate notably occurred at some production wells. Doddy et al. (2000) explained the 


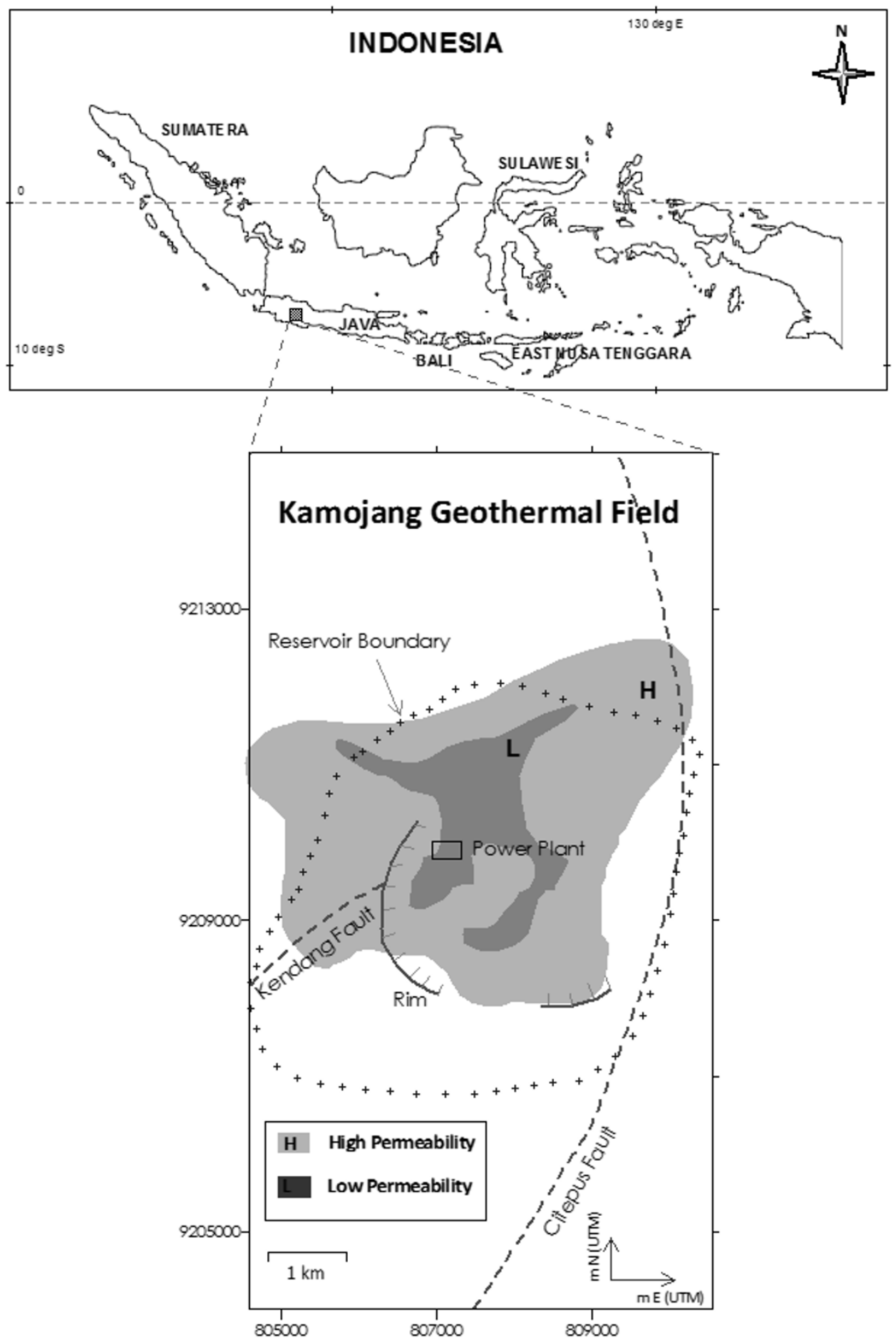

Fig. 1. Location of KGF with direction of the Citepus and Kendang fault and reservoir boundary from MT interpretation.

decline rate of the production wells using the type curve matching in 1999 is about 7.43\%/year. Repeat gravity measurements have been conducted to monitor the change in the geothermal reservoir throughout exploitation.

Repeat gravity measurement or microgravity techniques have been applied to the investigation of dynamic processes in various types of volcanoes and geothermal eld. Gravity changes enable the characterization of subsurface processes: i.e., the mass of the intrusion or hydrothermal ow (Rymer et al., 1998; Battaglia et al., 2003). Variation in mass at geothermal elds also can be monitored using this method. Gravity changes for a period of time during exploitation of the geothermal reservoir may show places where gravity has increased or decreased. The temporal gravity changes can provide insight into mass variation and indicate the location of places where net mass loss or gain occurred. Measurements of repeat gravity are pertinent to the assessment of natural recharge into the reservoir and its increase in response to production-induced pressure decline (Hunt, 1970; Geri et al., 1985; Allis and Hunt, 1986; Nordquist et al., 2004). Gravity data have been evaluated to provide the mass balance model of the Kamojang geother- 
Table 1. Correction and calculation of RGM method at KGF.

\begin{tabular}{|c|c|c|c|}
\hline Correction factors & Difference & Correction types & At the KGF \\
\hline Variation with position & $\begin{array}{l}\text { - The difference height above sea level } \\
\text { (about } 300 \mu \mathrm{Gal} / \mathrm{m} \text { ) } \\
\text { - The difference latitude position } \\
\text { (about } 0.8 \mu \mathrm{Gal} / \mathrm{m} \text { ) } \\
\text { - The difference longitude position } \\
(<0.01 \mu \mathrm{Gal} / \mathrm{m} \text { ) }\end{array}$ & Height and tide correction & calculated \\
\hline Variation with time & The difference position of the sun and moon & Tide correction & calculated \\
\hline Drift & $\begin{array}{l}\text { The difference condition of gravimeter } \\
\text { (It can be caused by the movement of } \\
\text { the instrument) }\end{array}$ & Drift correction & calculated \\
\hline $\begin{array}{l}\text { Topographic change/ } \\
\text { Ground subsidence }\end{array}$ & The difference elevation of the station & $\begin{array}{l}\text { Free air correction } \\
\Delta g_{v}=\frac{d g}{d z} \Delta h \text { (Telford } \text { et al., 1976) }\end{array}$ & calculated \\
\hline $\begin{array}{l}\text { Variation in shallow } \\
\text { groundwater level }\end{array}$ & $\begin{array}{l}\text { The difference of the shallow groundwater } \\
\text { volume (the rainfall rate changes) } \\
\text { (about } 5-10 \mu \mathrm{Gal} \text { (Goodkind, 1986)) }\end{array}$ & $\begin{array}{l}\Delta g_{w}=2 \pi G \rho \varphi(1-S) \Delta h \\
\text { (Hunt, 2000) }\end{array}$ & $\begin{array}{l}\text { Negligible } \\
\text { (The RGM in the } \\
\text { similar season) }\end{array}$ \\
\hline Variation in soil moisture & $\begin{array}{l}\text { The difference in the saturation } \\
\text { (The rainfall rate changes) }\end{array}$ & $\begin{array}{l}\Delta g_{a}=2 \pi G \rho \varphi \Delta S d \\
\text { (Hunt, 2000) }\end{array}$ & $\begin{array}{l}\text { Negligible } \\
\text { (The RGM in the } \\
\text { similar season) }\end{array}$ \\
\hline $\begin{array}{l}\text { Atmospheric pressure } \\
\text { variation }\end{array}$ & $\begin{array}{l}\text { The changes of air pressure } \\
(<5 \mathrm{hPa} \text { or about } 2 \mu \mathrm{Gal})\end{array}$ & Air pressure correction & $\begin{array}{l}\text { Negligible } \\
\text { (It is too small) }\end{array}$ \\
\hline Active volcanism & $\begin{array}{l}\text { The emplacement of the magma at } \\
\text { shallow depths }\end{array}$ & Volcanism correction & $\begin{array}{l}\text { Negligible } \\
\text { (No relation to } \\
\text { location of the KGF) }\end{array}$ \\
\hline Mining operation & $\begin{array}{l}\text { The removal of mineral ore, rock and } \\
\text { other mining from underground }\end{array}$ & Mass change correction & $\begin{array}{l}\text { Negligible } \\
\text { (No relation to } \\
\text { location of the KGF) }\end{array}$ \\
\hline $\begin{array}{l}\text { Variation of the } \\
\text { surrounding area }\end{array}$ & $\begin{array}{l}\text { The difference surface topography of } \\
\text { the terrain (such as construction of canal, } \\
\text { road, etc.) }\end{array}$ & Terrain correction & $\begin{array}{l}\text { Negligible } \\
\text { (It is too small } \\
\text { in the KGF) }\end{array}$ \\
\hline
\end{tabular}

mal system. Exploitation of the geothermal system often causes vertical ground movement. Therefore the correction of elevation changes to the observed gravity in each station has been conducted. In the KGF the elevation data were collected from leveling surveys.

\section{Method and Data Acquisition}

\subsection{Repeat Gravity Measurement (RGM) setup}

The RGM is also called as microgravity measurement, generally used to distinguish data in the range of 1$500 \mu \mathrm{Gal}$ from those in geophysical prospecting (Bouguer anomalies) which usually lie in the range 500-100,000 $\mu$ Gal (0.5-100 mGal, Hunt, 2000). The differences in the earth gravity value of one benchmark at different times can be caused by variation of the topographic area, shallow groundwater level, atmospheric pressure variation and many other factors. We carried out this method with some corrections from the above factors such as elevation changes correction, free air correction and other correction factor (Table 1). Pertamina conducted gravity measurements and leveling surveys over the Kamojang area since 1984.

The relative gravity measurements before 2005 were done with LaCoste and Romberg type G 655 and G 653 gravimeters. These gravimeters are also added by the $b a$ sicmeter unit (galvanometer) which has high accuracy to read the relative gravity. The theodolite type water pass NAK2 universal automatic level was used to the level- ing survey. This theodolite has small deviation of about $1 \times 10^{-5} \mathrm{~mm} / \mathrm{m}$ (Kamah and team, 2000). Checking of the gravimeter and theodolite performance was made prior to and during the gravity and leveling survey. The calibration range of gravimeter was calculated at the start of each survey to check the data validation. Gravimeters were calibrated to the 2 gravity absolute points that have calibration distance about 20 to $30 \mathrm{~km}$. After 2005, relative gravity measurements have been performed using a Scintrex CG3 gravimeter. This gravimeter is automatic gravimeter with electronic advances. The basic of CG3 has a readout resolution of $5 \mu \mathrm{Gal}$ with a standard deviation of less than 10 $\mu \mathrm{Gal}$ (Scintrex CG-3, 1995). CG3 gravimeter demonstrates that standard deviation between individual reading and station means is less than $0.01 \mathrm{mGal}$. This relative gravimeter has high accuracy and low residual drift. Gravimeter also was calibrated to the gravity absolute point. Gravity measurements in 2009 and 2010 used A10 absolute gravimeter, which is a portable absolute gravimeter. This has good precision and accuracy factor of $10 \mu \mathrm{Gal}$. The A10 uses laser, interferometer, long period inertial isolation device and an atomic clock to measure the position of the test mass very accurately (Micro-g LaCoste Inc., 2006).

According to relative gravimeter measurement, the round measurement method of the earth gravity eld in the KGF was conducted with PG 55, the gravity benchmark outside of the Kamojang reservoir boundary, as a reference gravity point. It is assumed that gravity remained constant at 


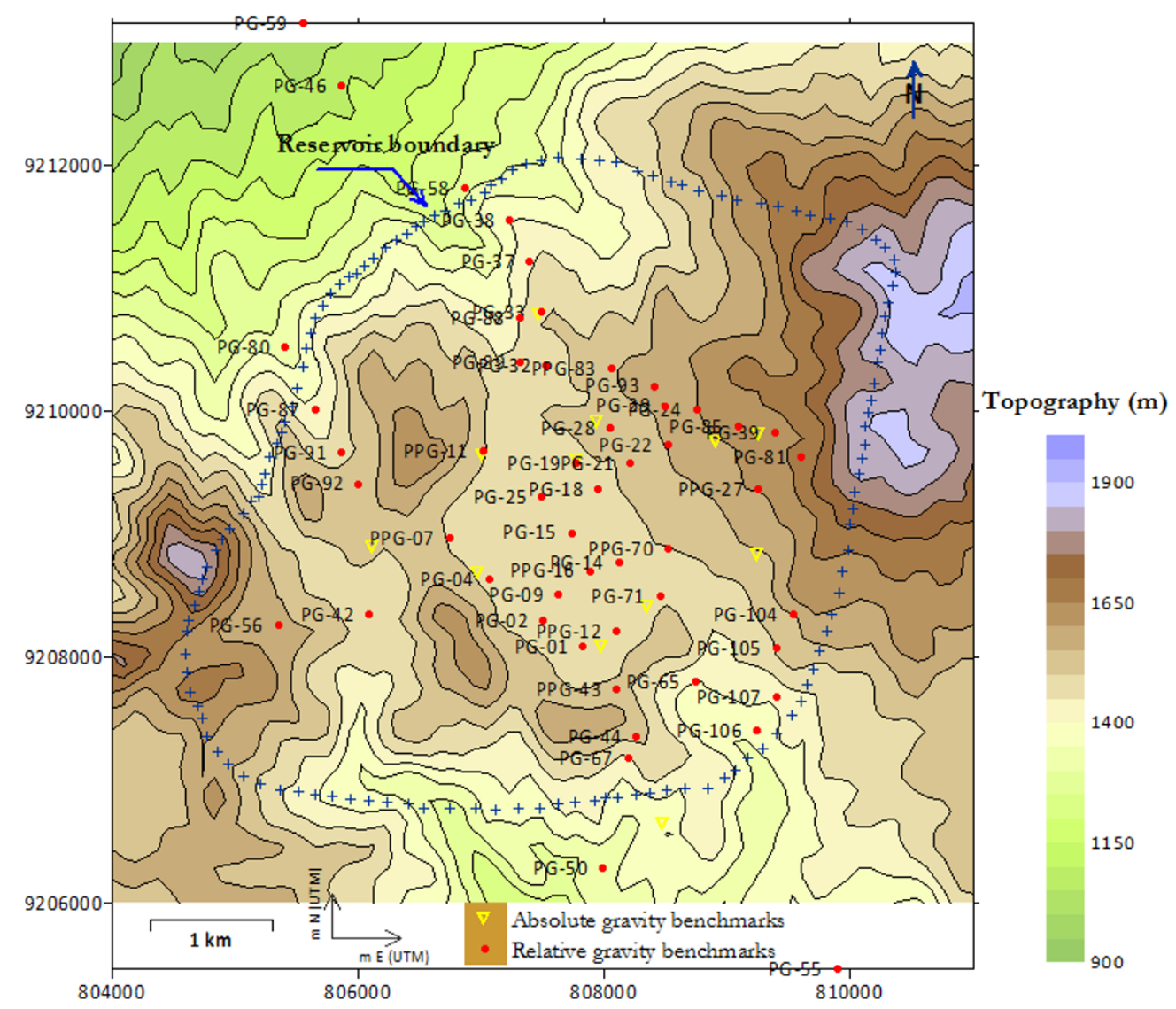

Fig. 2. Relative (red dot) and absolute (yellow diamond) gravity benchmarks at the KGF.

the reference. Location of PG 55 can be seen in the Fig. 2. The close looping technique of the gravity measurements was conducted to minimize the drift errors and to identify shock induced tares. A careful field technique and repeat readings was made to minimize these uncertainties. In one close looping we obtained minimum two gravity data in each benchmark. Gravity measurements were conducted on the flat benchmarks that were inserted $110 \mathrm{~cm}$ to subsurface ( ize $40 \mathrm{~cm}$ lengths $\times 40 \mathrm{~cm}$ wide $\times 150 \mathrm{~cm}$ height). Validation of the observed gravity data limited by the drift correction factor has less than $20 \mu \mathrm{Gal}$. The RGM and the leveling surveys in first period (1999-2005) consist of a network of more than 51 benchmarks and cover an area of about 35 $\mathrm{km}^{2}$. Measurement in 2008 is only 30 benchmarks due to some benchmarks were lost or broken.

There are 12 absolute gravity benchmarks in 2009 and 2010 measurement. These absolute gravity benchmarks were selected with available location. We need locations that have flat surface, enough area for absolute gravity equipment, small noise and good contact with the ground. Mostly located inside of the reservoir boundary and there is one absolute gravity benchmark located outside of reservoir area. It took about 50 minutes for one site measurement. Actually we did not need a gravity reference benchmark for gravity measurement with absolute gravimeter. We directly have absolute gravity value for each gravity benchmark. In a relative gravity measurement, we assumed that the gravity at the reference station does not change. But observed gravity changes include the uncertainty of the reference sta- tion, and we cannot separate this uncertainty using relative gravity measurement. Absolute gravimetry can measure the temporal gravity changes unequivocally (Nishijima et al., 2010). Absolute and relative gravity benchmarks in Kamojang Geothermal Field are also shown in Fig. 2.

\subsection{Correction factors}

The observed gravity and elevation data were mostly centered in the Kamojang reservoir but some observed data are located outside of the reservoir area. Hunt (2000) explained the correction factors of the gravity measurement were classified into the correction of variations with position, variations with time and changes in position of mass in the earth. The correction and calculation were applied in the data processing of the observed gravity data in KGF are shown in Table 1. Hunt (1970) explained that the elevation change correction is very important in order to interpret the gravity changes map. Drift, height and tide corrections are the standard correction factors that have to be calculated in the gravity measurement.

The observed gravity data were firstly corrected for tide, height and drift corrections. Some of these corrections were directly provided by gravimeters and the rest were estimated manually. All the gravity data at the benchmarks in 1999 and 2005 have elevation data. These elevation data were used to the vertical ground movement correction. The correction for the change in the ground movement was done with $(d g / d z) \Delta h$. Telford et al. (1976), explained the gravity field changes by the ground movement changes $(\mathrm{dg} / \mathrm{dz})$ of about $0.3085 \mathrm{mGal} / \mathrm{m}$. Our elevation data between 1999 


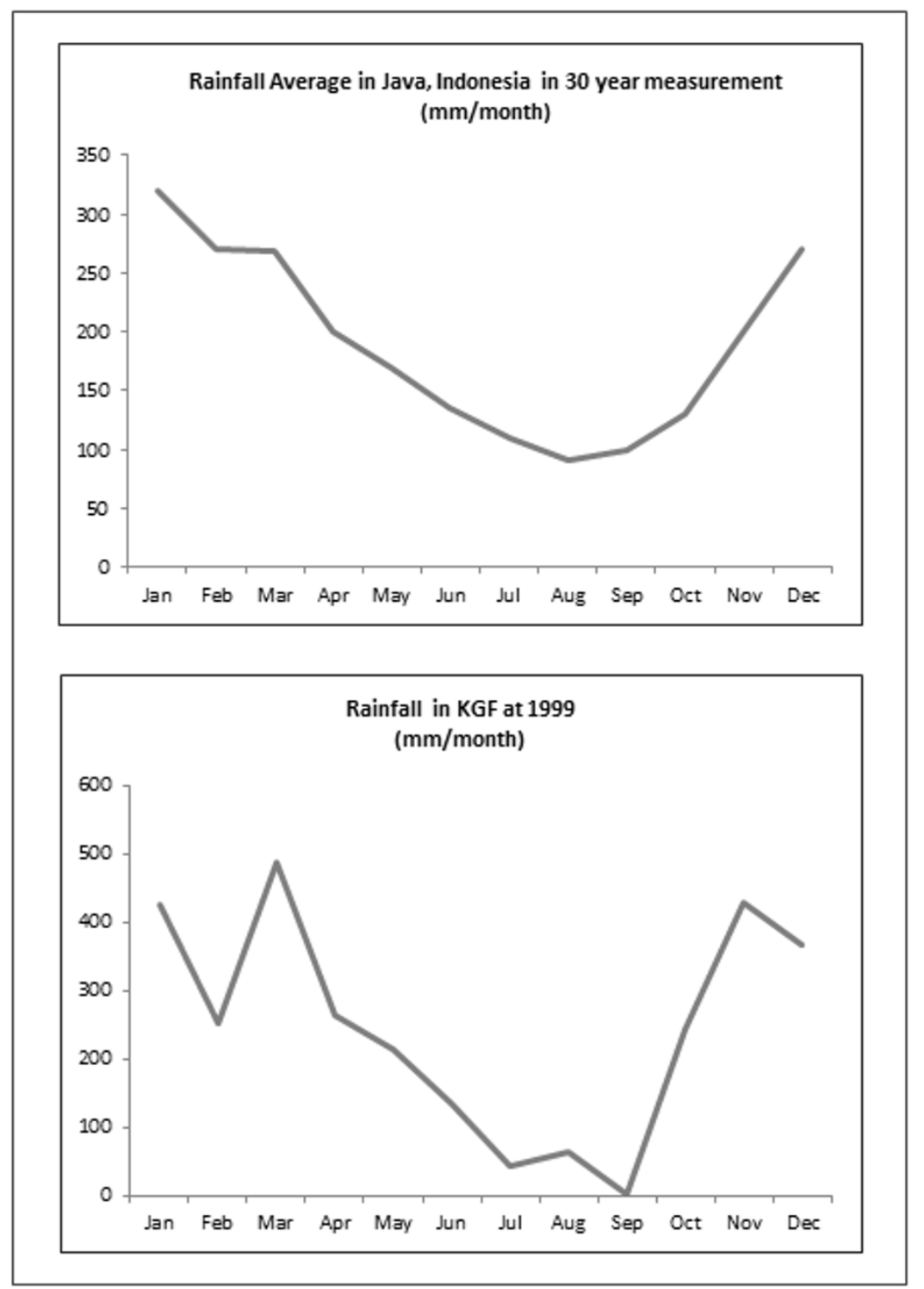

Fig. 3. The 30 years rainfall data in Java, Indonesia and the 1999 rainfall data at the KGF.

and 2005 did not reveal any signi cant ground deformation. Vertical displacement maximum of benchmark were found about $\pm 2 \mathrm{~cm} /$ year or corresponding to free air effect of \pm 5 $\mu \mathrm{Gal}$. The average negative vertical displacement from 16 gravity benchmarks is about $-0.6 \mathrm{~cm} /$ year or corresponding to free air effect less than $-2 \mu \mathrm{Gal}$. According to this elevation data, we assumed the elevation data in 2008 similar to 2005 is caused by a short difference period of measurement.

The seasonal changes in the shallow groundwater level can have a signi cant effect to the microgravity data (e.g. Allis and Hunt, 1986). Therefore the time of the gravity measurements in 1999, 2005, 2008, 2009 and 2010 were scheduled during the dry season around July to September. The same season of gravity measurement gave relatively similar data of saturation and groundwater level at that area. The maximum gravity change that associated with changes in soil moisture of sand and silt is about $12 \mu \mathrm{Gal}$ of amplitude (Hunt, 2000). From 30 years measurement, Aldrian and Susanto (2003) explained the rainfall rate of the region A of Indonesia (including the Java Island) in July to Oc- tober is in low part of the rainfalls rate in Indonesia. The dry season around July to September also can be seen in the local rainfall rate measurement at the Kamojang area in 1999 (Kamah and team, 2000). Rainfall data in Indonesia and Kamojang area can be seen in Fig. 3. The changes in the shallow ground water level were calculated in 16 shallow wells of the local people around Kamojang Geothermal Field to prove above assumption. These wells were located near gravity benchmarks and the depths of water table were measured in 1999 and 2005. The density of water and the rock porosity were assumed to be $1 \mathrm{gr} / \mathrm{cc}$ and $15 \%$. Referring to the equation of the changes of shallow ground water level (see equation in the Table 1), the correction of this factor has been estimated for the observed gravity changes. The gravity correction that is caused by shallow groundwater level changes have average value of about $0.845 \mu \mathrm{Gal}$. The groundwater level changes mostly occured in local wells that were located in the reservoir boundary (Fig. 4). It was very small and this correction factor can be ignored. 


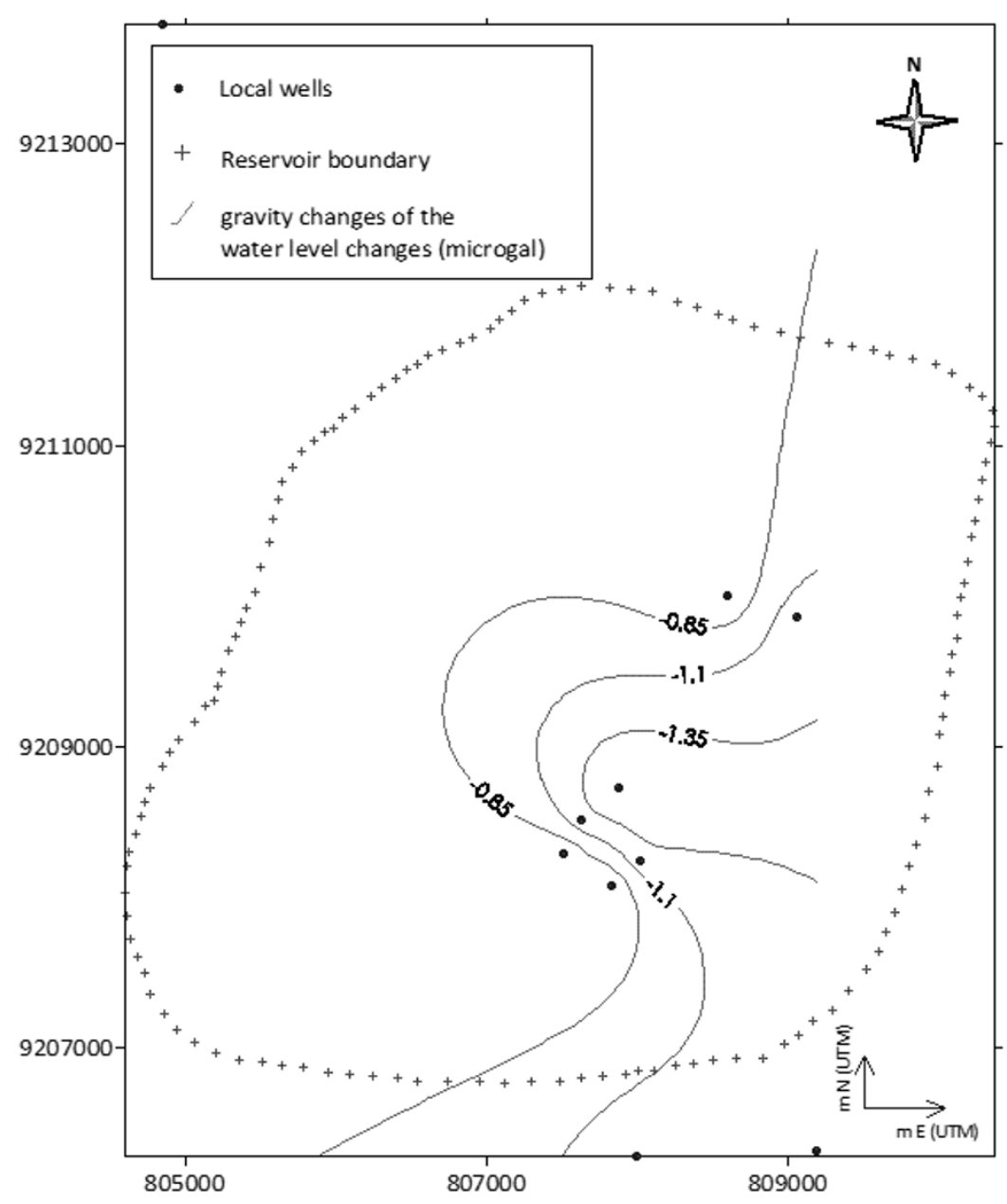

Fig. 4. The 1999-2005 shallow groundwater level changes at KGF.

According to gravity data in 2009 and 2010 from absolute gravimeter, data acquisition of Micro-g LaCoste absolute gravimeter use software ' $\mathrm{g}$ ' version 7. This software is designed to acquire and process the raw gravity data. This software needs input of some parameteres and geophysical corrections data. We can correct directly the effects of the earth tide, ocean load, barometric pressure and polar motion in acquiring the absolute gravity data (Nishijima et al., 2010).

\section{Gravity Changes Results}

Temporal residual gravity changes recorded over benchmarks were evaluated in terms of mass variation in subsurface. The contouring of gravity changes in Fig. 5 used long wavelength over $500 \mathrm{~m}$. This method was carried out after smoothing the data to remove some variations (Sugihara and Ishido, 1998). The comparison of gravity changes from three different times (1999-2005, 1999-2008 and 20092010) in this area was dominated by negative contour or associated with mass decrease. The smoothed contouring data of long wavelength have various gravity changes range that can be seen in Fig. 5 .

The consideration of observation in 1999-2005 and 1999-2008 periods (instead of 2005-2008) is to evaluate an average mass decrease since 1999 as a reference point of decline production in the KGF (Doddy et al., 2000).
Another observed period (2009-2010) evaluates the condition of gravity changes after increase production at late 2007. Repeated gravity measurements in 2009 and 2010 were conducted using A-10 absolute gravimeter.

\subsection{9-2005 gravity changes}

The distribution of the gravity changes helps to give a picture of the mass movements that have occurred as a result of the production and injection activities between 1999 to 2005 and natural recharge from outside of the reservoir. The biggest negative gravity change occured on benchmark PPG-07 that is supported with the negative gravity changes on benchmarks PPG-11, PG-04 and PG-02 (see the location of gravity benchmarks in Fig. 2). This high negative value of the gravity change has correlation with the high production rate in this area, that are the KMJ-22, 37, 42, 65,73 and KMJ-74 (see the location of production wells in Fig. 5). The large negative gravity changes were primarily caused by the net mass loss of geothermal uids from the geothermal reservoir due to exploitation. The small positive value of the gravity change occurred near the injection wells KMJ-55 and KMJ-21. The gravity changes are larger in the high permeability zone.

\subsection{9-2008 gravity changes}

The gravity data in 2008 measurement have an uncertainty average about $12 \mu \mathrm{Gal}$. The distribution of the gravity changes helps to give a picture of the mass movements 


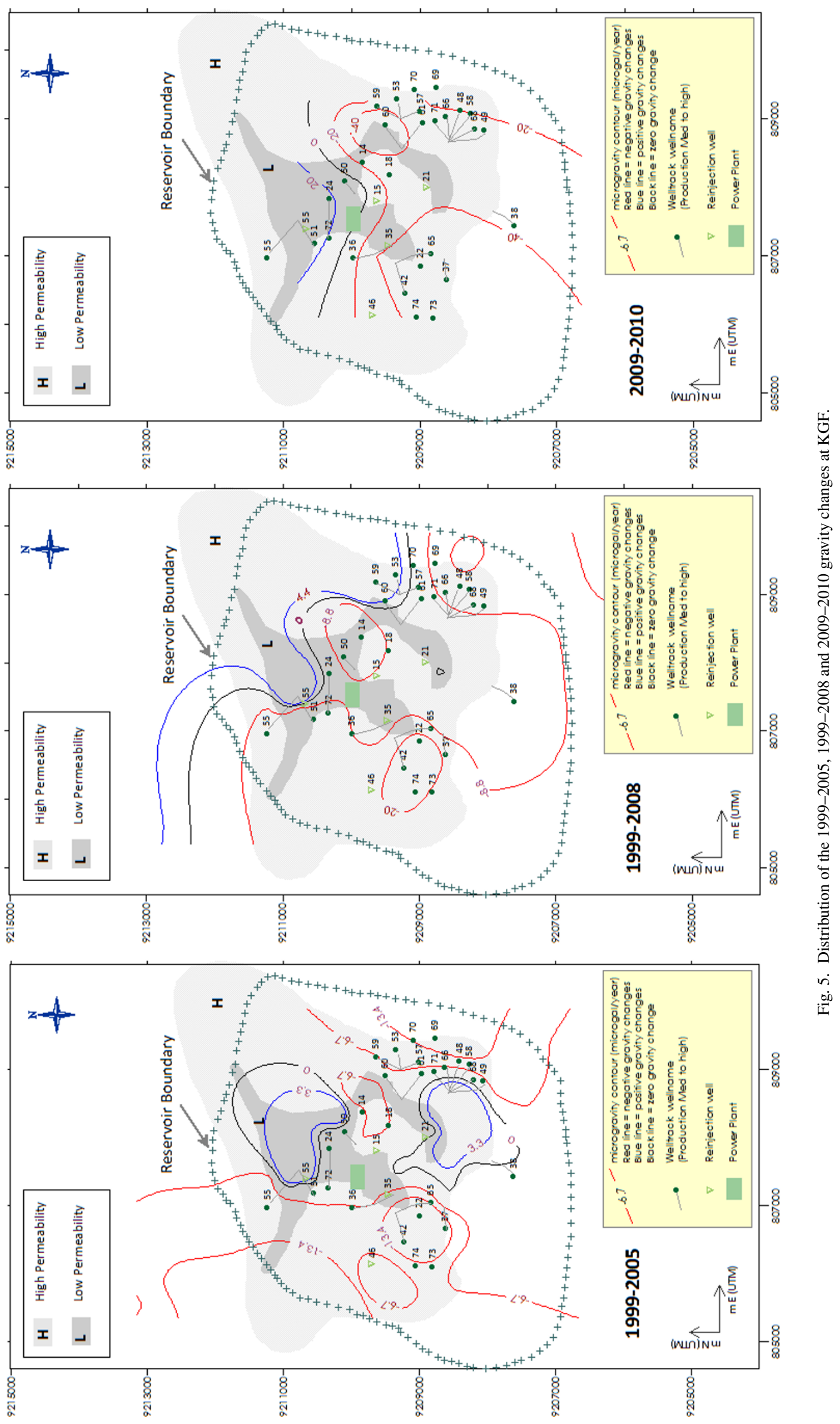


that have occurred as a result of the production and injection activities between 1999 and 2008 and natural recharge from outside of the reservoir. The gravity changes in this period is larger than that is obtained in the previous period. This is caused by the longer period and increase production capacity at 2007 . Some make up wells were added and some stand by wells were reactivated according to this inclined production. In this period, the biggest negative gravity change also occured on bechmark PPG-07 that correlated to high production zone. Some strike-slip faults from geology data in the north-east area at KGF are also correlated to the gravity changes distribution between 1999 and 2008. This area has a boundary between positive and negative gravity changes.

\section{$3.32009-2010$ gravity changes}

Gravity measurement using absolute gravimetry in 2009 and 2010 indicated small scattered data and uncertainty factor. Mostly uncertainties of the data are close to $10 \mu \mathrm{Gal}$ as accuracy of the A10 absolute gravimeter. There are two gravity data have uncertainty bigger than $12 \mu \mathrm{Gal}$. According to this condition, we reduced gravity data of these two benchmarks in the interpretation and mass change calculation. The distribution of the gravity changes in this period is look similar trend with the previous period in 1999 to 2008 gravity change. The positive gravity changes located in the northern part of the reservoir area at Kamojang Geothermal Field. Reservoir area with many production wells have negative gravity changes. The gravity changes in this period is the largest compared to the gravity changes average rate of two previous periods. This is caused by the production capacity at this period is bigger than them. Some make up wells were continue added and some stand by wells were reactivated according to this high production demand. The distributions of these gravity changes in three periods (1999-2005, 1999-2008 and 2009-2010) are shown in Fig. 5.

\section{Mass Balance}

A mass balance or material balance is an application of the mass conservation to the analysis of physical systems. The mass balance is used to analyze and to count the mass that enters or leaves the system. The mass balance in the geothermal reservoir is regulated by the amount of production, injection and natural recharge. Gauss's theory (Hammer, 1945; Hunt, 2000) explains the mass variations are obtained by gravity changes:

$$
\Delta m=\frac{1}{2 \pi G} \Sigma(\Delta g . \Delta A)
$$

where $\Delta m=$ the mass changes $(\mathrm{kg}), \Delta g=$ the gravity changes $(\mathrm{mGal}), \Delta A=$ Area concerned $\left(\mathrm{km}^{2}\right), G=$ the gravitational constant $6.672 \times 10^{-11} \mathrm{~N} \mathrm{~m}^{2} \mathrm{~kg}^{-2}$. The gravity change $\Delta g$ for each grid as calculated below:

$$
1 \Delta g=\frac{d g_{i, j}+d g_{i+1, j}+d g_{i, j+1}+d g_{i+1, j+1}}{4}
$$

where $\left(d g_{i, j}, d g_{i+1, j}, d g_{i, j+1}, d g_{i+1, j+1}\right)$ are the gravity change at one grid square.

This method has advantage in the way of averaging gravity changes in each grid area. It means that these results will also averaging and reducing some uncertainty factors of these gravity data. In the simple error propagation analysis, uncertainty in some observed variables can be combined become nal result. The nal result determines a smaller uncertainty than total error. Error propagation $\delta R$ in general functions $R$ can be written as:

$$
\delta R=\sqrt{\left(\frac{\partial R}{\partial X} \delta X\right)^{2}+\left(\frac{\partial R}{\partial Y} \delta Y\right)^{2}+\cdots}
$$

$R$ is a function of variables $X, Y$ and other variables $(R(X, Y, \ldots))$.

In this mass variation analyses at KGF by applying Gauss's potential theorem to gravity change data, we could not avoid "error in tailing off" and "error in gravity datum" (Hammer, 1945; Sugihara and Ishido, 1998). Gravity measurement at KGF could not cover the whole area, particularly in NE and SW part. This is very hard areas to access for conducting gravity monitoring regarding to the mountainous and steep area. Previous gravity data covered small area only about $25 \mathrm{~km}^{2}$. According to this analysis, we make assumption to manage these problems. We expected that gravity changes data in larger area will make a close loop of Gaussian method.

\subsection{Mass balance result}

4.1.1 1999-2005 The corrected gravity changes map was divided into grids. From the above calculation, the mass changes of the 1999-2005 gravity changes show decrease about $-20.07 \mathrm{Mt}$ (Million ton) for 6 years period or equal to $-3.34 \mathrm{Mt} / \mathrm{year}$. Since 1983 to 2005 , more than $160 \times 10^{6}$ tons of steam has been exploited from KGF and more than $30 \times 10^{6}$ tons of water has been injected to KGF. More than 30 production wells, including standby wells, supplied steam to the three units. The total production rate from the eld has remained relatively constant. History of the production and injection rate at KGF can be seen in Fig. 6. The average of total production rate from the 1999-2005 is about $7.98 \mathrm{Mt} /$ year. It is bigger than the average of the 1999-2005 total injection rates of 1.87 Mt/year (Pertamina, 2008). The net mass produced (total mass produced-total mass injected) at the KGF during this period is about $6.11 \mathrm{Mt} /$ year. Assuming all the injected water entered to the reservoir, the estimation of the total rate of the natural recharge to the Kamojang reservoir system is about $2.77 \mathrm{Mt} / \mathrm{year}$. The recharge rate to $\mathrm{KGF}$ of about $45 \%$ of the net mass produced has occurred from the natural ow and lateral aquifers. Mass balance model between 1999 and 2005 in the Kamojang geothermal reservoir was shown in Fig. 7.

4.1.2 1999-2008 Regarding same method to the previous mass changes calculation, during 1999 to 2008, the mass variation is equal to a $-3.78 \mathrm{Mt} /$ year. Mass change in this period is bigger than previous period throughout increase production. In 2007, the Kamojang production capacity was improved during the increased install capacity to 200 MWe. More than 40 production wells supplied steam constantly (Sanyal et al., 2000). The average of the 19992008 total production rates per year increased to about 8.35 Mt/year. In this period, the injection rate decreased to $1.82 \mathrm{Mt} /$ year (Pertamina, 2008). The net mass produced 


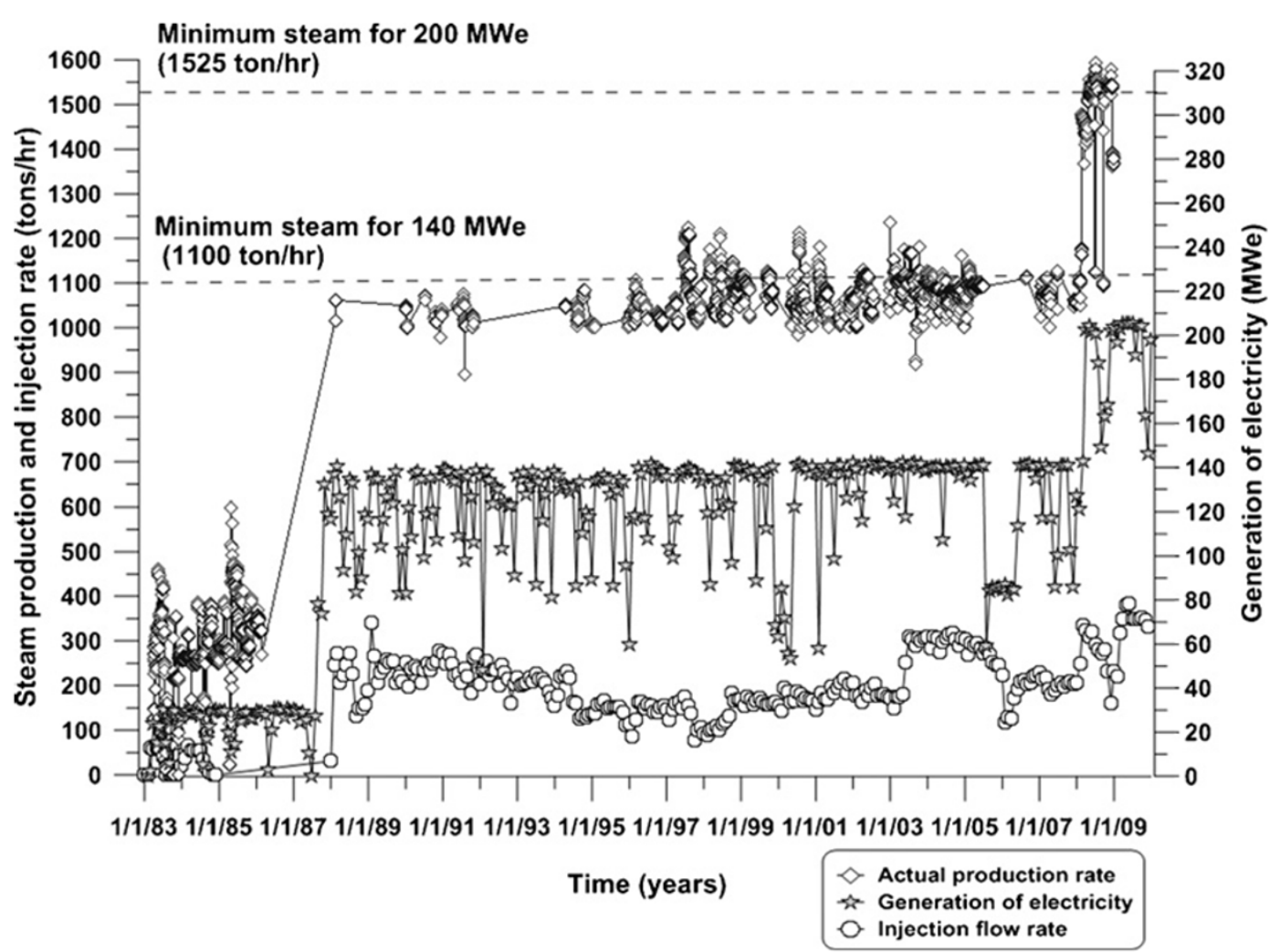

Fig. 6. The rate of the production and injection (ton/hour) at KGF (Suryadarma et al., 2010).

(total mass produced-total mass injected) at KGF during this period is about $6.53 \mathrm{Mt} / \mathrm{year}$. The natural recharge to the Kamojang reservoir system in this period is about $2.75 \mathrm{Mt} /$ year if all injected water entered to the reservoir. This high gap of the total amount between exploited and injected uid to the reservoir lead to unbalanced mass problem. Mass balance model between 1999 and 2008 in the Kamojang geothermal reservoir was shown in Fig. 7.

4.1.3 2009-2010 The mass change calculation of the 2009-2010 gravity changes shows a decreased mass about $-8.24 \mathrm{Mt} / \mathrm{year}$. This is very high decreased mass during very high production. We do not know the actual production in this period, but we estimated the average production will be about $13 \mathrm{Mt} /$ year (Sofyan et al., 2009; Suryadarma et $a l ., 2010)$. If the production rate in this period is guessed about $13 \mathrm{Mt} /$ year and injection rate is stable at $2 \mathrm{Mt} /$ year, then the natural recharge is about $2.76 \mathrm{Mt} /$ year. This natural recharge result is similar with previous period result $(2.77$ Mt/year for 1999-2005 and 2.75 Mt/year for 1999-2008). This is raw estimation of production and injection rate in this period 2009-2010 to make a mass balance model (see Fig. 7).

\section{Discussion}

Mass variation data throughout production activity in geothermal eld can be referred to monitor geothermal reservoir. Reservoir monitoring in Kamojang Geothermal Field needs many historical data. There are some historical facts correlated to this mass variation data. The history of previous research at Kamojang Geothermal Field explained a declined production trend since last decade (Doddy et al.,
2000; Moeljanto, 2004). The decline of steam ow rate notably occurred at some production wells. Concerning to the evaluation of steam production, it explained the decline rate of the production wells using type curve matching in 1999 is about $7.43 \%$ per year (Doddy et al., 2000). Production and injection history in this geothermal eld also show total production rate is much bigger than injection rate. There is high gap between production and injection amount in Kamojang Geothermal Field.

History of microgravity data at this eld was rst interpreted in 2000 (Pertamina, 2008). The calculation results of natural recharge rate per year from this microgravity interpretation between 1984 and 1999 of gravity changes data is $2.71 \mathrm{Mt} /$ year (Kamah and team, 2000). This result is almost similar with natural recharge rates between 1999 and 2005 (2.77 Mt/year), 1999-2008 (2.75 Mt/year) and 20092010 (2.76 Mt/year). This means that mass variation of natural recharge rate to the reservoir in Kamojang Geothermal Field is limited. The simple mass balance model of the 1999-2005, 1999-2008 and 2009-2010 gravity changes in KGF are shown in Fig. 7.

\section{Conclusions}

The gravity changes from the repeat gravity measurement (RGM) directly illustrate the mass variation in the subsurface. The distribution of the corrected gravity changes at the Kamojang Geothermal Field helps to give an image of the mass movements that occurred as a result of exploitation. The long wavelength above about $500 \mathrm{~m}$ of corrected gravity changes contour data in these three periods has a various range with similar trends. The negative value is inter- 

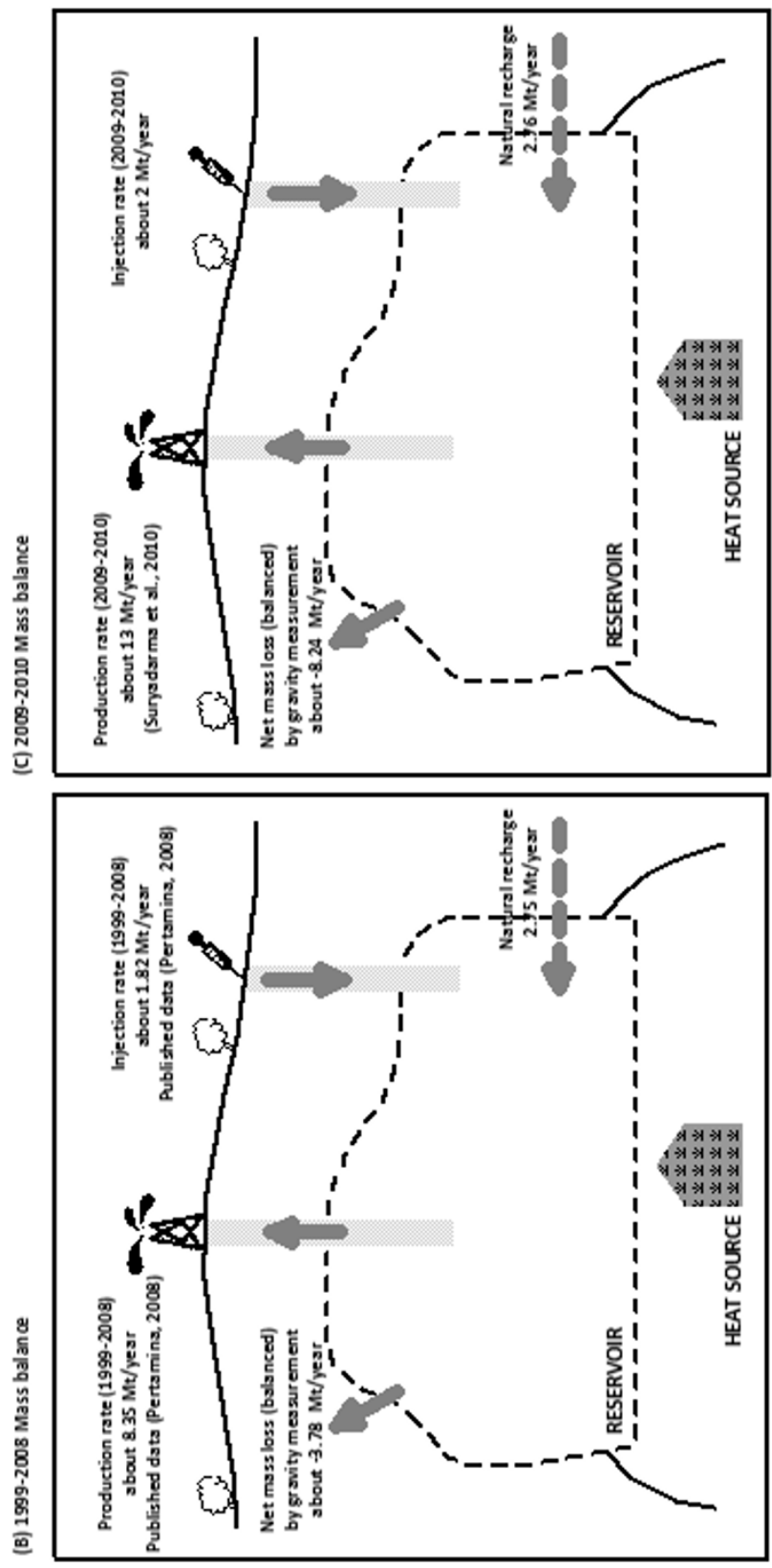

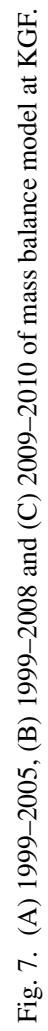

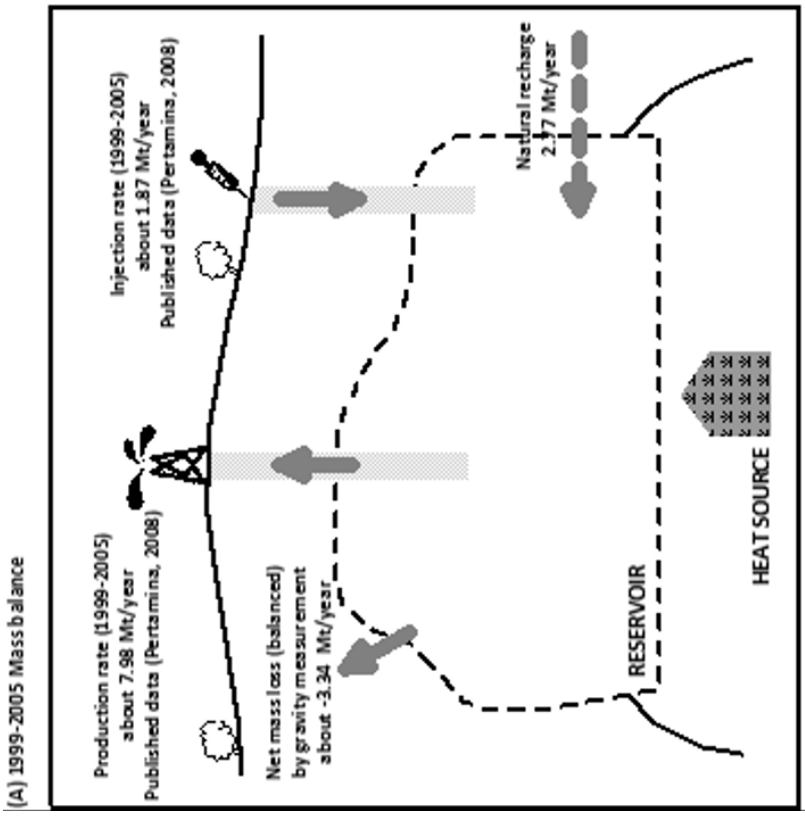


preted in terms of net mass loss of production and the positive value is interpreted in terms of net mass gain of water injection and natural recharge. Large negative anomaly typically occured at the gravity benchmarks that located near to medium or high production wells. This large negative gravity changes were primarily caused by the net mass loss of steam from the geothermal reservoir due to exploitation. The small positive value of the gravity change occurred near the injection wells KMJ-55 and KMJ-21. The gravity changes is larger in the high permeability zone.

In the six years production period (1999-2005), the Kamojang Geothermal Field has mass decrease of about -3.34 Mt/year. The 1999-2005 net mass produced (total mass produced-total mass injected) from this period is about $6.11 \mathrm{Mt} / \mathrm{year}$. Assuming all the injected water enters to the reservoir, the total rate of the natural recharge to the Kamojang reservoir system is about $2.77 \mathrm{Mt} /$ year. After the produced capacity increased to $200 \mathrm{MWe}$ at 2007 at KGF, repeat gravity measurement was conducted in the end of 2008 that was compared to 1999. The estimated mass changes rate from the 1999-2008 gravity changes data is decreased mass of about $-3.78 \mathrm{Mt} / \mathrm{year}$. The net mass produced at KGF during this period is about $6.53 \mathrm{Mt} / \mathrm{year}$. The natural recharge to the Kamojang reservoir system in this period is about $2.75 \mathrm{Mt} /$ year if all injected water entered to the reservoir. Mass change calculation of the 20092010 gravity changes shows a decreased mass about -8.24 Mt/year.

Three gravity comparison between the 1999-2005, 1999-2008 and 2009-2010 have different situation of the production capacity. Gravity changes rate during 20092010 period is the biggest one. This is caused by the largest production capacity if it is compared to previous periods. During the increase production, the net mass loss will continue increase and affect an unsustainable production.

Acknowledgments. I would like to thank PERTAMINA for his permission in monitoring study of his area at Kamojang Geothermal Field. We also thank to Research Institute for Humanity and Nature (RIHN) for gravity measurement using Absolute gravimeter. I acknowledge the nancial support of KAKENHI (Grant-inAid for Scienti c Research by Japan Society for the Promotion of Science) Category B (No. 21404018) for gravity measurement in Kamojang Geothermal Field.

\section{References}

Aldrian, E. and D. Susanto, Identi cation of three dominant rainfall regions within Indonesia and their relationship to sea surface temperature, Int. J. Climatol., 23, 1435-1452, 2003.

Allis, R. G. and T. M. Hunt, Analysis of exploitation-induced gravity changes at Wairakei geothermal eld, Geophysics, 51, 1647-1660, 1986.

Battaglia, M., P. Segall, and C. Roberts, The mechanics of unrest at Long Valley caldera, California: 2. Constraining the nature of the source using geodetic and micro-gravity data, J. Volcanol. Geotherm. Res., 127, 219245, 2003.

Doddy, S., I. K. Sujata, and U. Komaruddin, Evaluation of steam production decline trends in the Kamojang Geothermal Field, Proceedings World Geothermal Congress 2000, Kyushu, Japan, 2857-2862, 2000.

Geri, G., I. Marson, A. Ross, and B. Toro, Crustal deformation and gravity changes during the rst ten years of exploitation of the new travale Radicondoli geothermal eld, Italy, Geothermics, 14, 273-285, 1985.

Goodkind, J. M., Continuous Measurement of non-tidal variations of gravity, J. Geophys. Res., 91, 9125-9134, 1986.
Hammer, S., Estimating ore masses in gravity prospecting, Geophysics, 10, 50-62, 1945.

Hochstein, M. and P. Sudarman, History of geothermal exploration in Indonesia from 1970 to 2000, Geothermics, 37, 220-266, 2008.

Hunt, T. M., Gravity changes at Wairakei geothermal eld, New Zealand, Geol. Soc. Am. Bull., 81, 529-536, 1970.

Hunt, T. M., Five lectures on environmental effect of geothermal utilization, Geothermal Training Programme United Nations University, 104 pp., 2000.

Kamah, M. Y., T. Dwikorianto, A. A. Zuhro, D. Sunaryo, and A. Hasibuan, The productive feed zones identi ed based on spinner data and application in the reservoir potential review of Kamojang Geothermal Area, Indonesia, Proceedings World Geothermal Congress, 2005, Turkey, 6 pp., 2005.

Kamah, M. Y. and team, Gravity Survey Report 99-00 Kamojang Geothermal Field, Jawa barat. OPS Eksplorasi Panasbumi, Divisi panasbumi Dit. EP-PERTAMINA, 93 pp., 2000.

Micro-g LaCoste Inc., A10 Portable Gravimeter User's Manual, 7 pp., 2006.

Moeljanto, Evaluation of the environmental impact at the Kamojang Geothermal Field in Indonesia applying the ems of iso 14001, Report of Geothermal Training Programme, 209-238, The United Nation University, Iceland, 2004.

Nishijima, J., H. Saibi, Y. Sofyan, S. Shimose, Y. Fujimitsu, S. Ehara, Y. Fukuda, T. Hasegawa, and M. Taniguchi, Reservoir monitoring using hybrid micro-gravity measurement in the Takigami Geothermal Field, Central Kyushu, Japan, Proceedings World Geothermal Congress 2010, Bali, Indonesia, 6 pp., 2010.

Nordquist, G., J. A. P. Protacio, and A. Acuna, Precision gravity monitoring of the Bulalo geothermal eld, Philippines: Independent checks and constraints on numerical simulation, Geothermics, 33, 37-56, 2004.

Pertamina, Kamojang, West Java Indonesia, from beginning until now, International Geothermal Sustainability Modeling Workshop, New Zealand, 10 pp., 2008.

Rymer, H., J. Cassidy, C. A. Locke, and F. Sigmundsson, Post-eruptive gravity changes from 1990 to 1996 at Kra a volcano, Iceland, J. Volcanol. Geotherm. Res., 87, 141-149, 1998.

Sanyal, S. K., A. Robertson-Tait, S. J. Butler, J. W. Lovekin, P. J. Brown, S. Sudarman, and S. Sulaiman, Assessment of steam supply for the expansion of generation capacity from 140 to 200 MW, Kamojang Geothermal Field, West Java, Indonesia, Proceedings of World Geothermal Congress 2000, Japan, 2195-2200, 2000.

Scintrex CG-3/3M Autograv, Automated Gravity Meter Operator Manual, 198 pp., 1995.

Sofyan, Y., Y. Daud, Y. Kamah, J. Nishijima, Y. Fujimitsu, and S. Ehara, Sustainable production plan in the geothermal energy developmenta case study of Kamojang Geothermal Field, Indonesia, Proceedings the 4th International Symposium on Novel Carbon Resource Sciences, Shanghai, 141-147, 2009.

Sofyan, Y., Y. Daud, Y. Kamah, H. Saibi, J. Nishijima, Y. Fujimitsu, and S. Ehara, Monitoring of mass balance model during production capacity increase at Kamojang Geothermal Field, Indonesia, Proceedings 35th Workshop on Geothermal Reservoir Engineering, Stanford, 431-437, 2010.

Sudarman, S., M. Boedihardi, and K. Pudyastuti, Bardan, Kamojang Geothermal Field 10 year experience, Proceedings World Geothermal Congress 1995, Florence, 1773-1777, 1995.

Sugihara, M. and T. Ishido, Gravity monitoring at the Sumikawa Geothermal Field, Japan, Geothermal Resources Council Transactions, Vol. 22, 191-195, 1998.

Sumintadireja, P., S. Sudarman, H. Mizunaga, and K. Ushijima, Misse-ala-masse and gravity data survey at the Kamojang Geothermal Field, Proceedings World Geothermal Congress 2000, Kyushu, Japan, 17771784, 2000.

Suryadarma, T. Dwikorianto, A. Zuhro, and A. Yani, Sustainable development of the Kamojang geothermal eld, Geothermics, 39, 391-399, 2010.

Telford, W. M., L. P. Geldart, R. C. Sheriff, and D. A. Keys, Applied Geophysics, 770 pp, Cambridge University Press., Cambridge New York, 1976.

Y. Sofyan (e-mail: sofyan@aso.vgs.kyoto-u.ac.jp), Y. Kamah, J. Nishijima, Y. Fujimitsu, S. Ehara, Y. Fukuda, and M. Taniguchi 